\title{
Nutritive Quality of Leaf Proteins Coagulated at Different pH
}

\author{
Takao Horigome, ${ }^{1}$ Jong Kyu KIM ${ }^{2}$ and Senji UCHIDA ${ }^{1}$ \\ ${ }^{1}$ Faculty of Agriculture, Okayama University, \\ Tsushima, Okayama 700, Japan \\ ${ }^{2}$ College of Agriculture, Gyeong-sang \\ National University, Jinju 620, Korea
}

(Received March 24, 1983)

\begin{abstract}
Summary Leaf proteins obtained by coagulation at different $\mathrm{pH}$ were examined for their chemical composition and nutritional quality. Green juice was extracted from alfalfa, red clover, Italian ryegrass and oats and leaf protein was coagulated by heating the juice after adjusting the $\mathrm{pH}$ to 4 or $8-8.5$, or without any adjustment of the $\mathrm{pH}$ (about $\mathrm{pH} 6$ ). The mild alkaline juice from Italian ryegrass and oats did not cause the satisfactory coagulation but it was achieved with the addition of $\mathrm{Ca}$ salt to the juice before heating.

There were no important differences in the amino acid compositions of the leaf proteins coagulated at different $\mathrm{pH}$. Crude ash, $\mathrm{Ca}$ and $\mathrm{Mg}$ contents increased with an increase in $\mathrm{pH}$ of coagulation and the protein coagulated at $\mathrm{pH} 8$ had remarkably high contents of crude ash, $\mathrm{Ca}, \mathrm{Mg}, \mathrm{Na}$ and $\mathrm{P}$ in each crop. The leaf protein coagulated at $\mathrm{pH} 6$, on the contrary, had a high content of true protein and low contents of nitrogen free extracts and nucleic acid as compared with those at $\mathrm{pH} 4$ and 8 .

The $\mathrm{pH}$ of coagulation of leaf protein from alfalfa and red clover had no effect on the nutritional quality of the respective proteins. In Italian ryegrass and oats, however, the leaf protein coagulated at $\mathrm{pH} 8$ was found to be nutritionally inferior to those coagulated at a lower $\mathrm{pH}$.

The data presented in this work support that in general, the leaf protein produced by heating the green juice without any adjustment of $\mathrm{pH}$ may be suitable for protein resources because of its desirable properties, i.e. high true protein content and good nutritional quality.

Key Words leaf protein, protein digestibility, protein efficiency ratio, thermal coagulation, $\mathrm{Ca}, \mathrm{pH}$
\end{abstract}

Significant developments have been made in the research on the manufacturing process to obtain and edible protein from the green juice separated by the fractionation of green crops, but a heat treatment of green juice is one of the most

1 堀米隆男, ${ }^{2}$ 金 鍾奎, ${ }^{1}$ 内田仙二 
common methods. Subba Rau and Singh(1) showed that alfalfa leaf protein coagulated at $\mathrm{pH} 4-4.5$ was nutritionally inferior to that coagulated by heating at 5.9-6.2. Livingston et al. (2) reported that the thermal coagulation of protein at $\mathrm{pH}$ 6 gave as much as a four fold increase in saponin over that in the protein coagulated at $\mathrm{pH}$ 8. It was further demonstrated by Hegsted and Linkswiler (3) that alfalfa leaf protein containing low saponin had a higher nutritive quality than that containing high saponin. In addition, Enochian et al. (4) has stated that the adjustment of green juice to $\mathrm{pH} 8-8.5$ reduced proteolytic activity, stabilizes carotene and xanthophyll during processing and increases the firmness of coagulated curd. These results suggest that the thermal coagulation of leaf protein under mild alkaline conditions has several advantages over the coagulation of protein at $\mathrm{pH} 4-4.5$. However, these results and observations were based on the experiments conducted with the use of alfalfa as a green crop. The purpose of this study was to investigate the effects of $\mathrm{pH}$ coagulation on the nutritional quality of leaf protein with the use of several crops. Protein quality was evaluated by chemical analyses and biological tests.

\section{EXPERIMENTAL}

Sample preparation. Alfalfa, red clover, Italian ryegrass and oats were chosen for this study. Each crop was harvested before flowering or before earing. Freshly harvested crops were pulped with approximately equal amounts of water in weight and the green juice was expressed by a hand-press through muslin. The green juice was divided into three portions and three leaf-protein samples were prepared from each crop as follows:

1. $\mathrm{pH}$ 4-coagulated protein: prepared by heating the juice at $85^{\circ} \mathrm{C}$ after adjusting the $\mathrm{pH}$ of the juice to 44.5 with $10 \% \mathrm{HCl}$

2. $\mathrm{pH}$ 6-coagulated protein: prepared by heating at $85^{\circ} \mathrm{C}$ without any adjustment of $\mathrm{pH}$ of the green juice.

3. $\mathrm{pH}$ 8-coagulated protein: prepared by heating the juice at $85^{\circ} \mathrm{C}$ after adjusting the $\mathrm{pH}$ of the juice to $8-8.5$ with $10 \% \mathrm{NaOH}$.

The green juice from Italian ryegrass and oats did not coagulate satisfactorily on heating at $\mathrm{pH} 8-8.5$, but the coagulation of the alkaline juice was achieved with the addition of $\mathrm{CaCl}_{2}$ followed by heating. Thus, when the $\mathrm{pH}$ 8-coagulated protein was prepared from Italian ryegrass and oats, $\mathrm{CaCl}_{2}(\mathrm{Ca}, 2.1-2.7 \mathrm{~g})$ was added in the green juice (1 liter) and then the $\mathrm{pH}$ of the juice was readjusted to 8-8.5 before heating. Leaf protein coagulum was separated from the juice and most of the coagulum was washed with acetone repeatedly and the remainder being freezedried.

Chemical analysis. Nitrogen, crude fat, crude fiber, crude ash and moisture were determined by the official methods (5). Crude protein was estimated as the amount of $\mathrm{N} \times 6.25$. Atomic absorption spectrophotometry (Nippon Jarrell-ash, AA-80) was used for determining $\mathrm{Ca}, \mathrm{Mg}, \mathrm{K}$ and $\mathrm{Na}$. Each leaf protein was dry ashed at $500^{\circ} \mathrm{C}$ for determining these minerals (6). For total phosphorus, samples 
were wet digested with a mixture of nitric and sulfuric acids until the mixture became colorless. The modified Allen's method (7) was used for P determination. Nucleic acid in the leaf protein was determined using the following procedure. Acetone-washed leaf protein was extracted successively, by ethyl ether, cold $5 \%$ perchloric acid and hot $\left(70^{\circ} \mathrm{C}\right) 5 \%$ perchloric acid. $\mathrm{P}$ determined from the extract with hot perchloric acid was multiplied by a factor of 11 and this value was taken as the nucleic acid, including RNA and DNA (8).

The amino acid composition of leaf proteins was determined by ion exchange chromatography with an automated amino acid analyzer (Nihondenshi, JLC-6AH). The hydrolysis of leaf protein was carried out as described in the previous paper (9). Cyst(e)ine and tryptophan were not determined.

Biological test. Male rats of the Wistar strain weighing approximately $45 \mathrm{~g}$ were used for the assessment of acetone-washed leaf proteins. The protein quality of leaf proteins was estimated by the protein efficiency ratio (PER) and apparent protein digestibility. The basal protein-free diet was composed of $73.8 \%$ corn starch, $10.0 \%$ cane sugar, $10.0 \%$ corn oil, $4.0 \%$ mineral mix $(10), 1.0 \%$ vitamin $\operatorname{mix}(9), 1.0 \%$ cellulose powder and $0.2 \%$ L-methionine. Each leaf protein was added to the basal diet in place of an equal weight of corn starch to provide about $8 \%$ protein. Each diet group included five rats and diets were fed ad libitum for a 14-day period. The apparent digestibility was determined by analyzing the nitrogen intake and fecal nitrogen during the last three days of the period.

\section{RESULTS AND DISCUSSION}

\section{Leaf protein preparation}

$\mathrm{Ca}$ and $\mathrm{Mg}$ contents in the green juice from each crop are shown in Table 1. There were larger amounts of $\mathrm{Ca}$ and $\mathrm{Mg}$ in the green juice from legume crops (alfalfa and red clover) than in the original green juice from grasses (Italian ryegrass and oats). In particular, the $\mathrm{Ca}$ content in the green juice from legume crops is more than double that in the juice from grasses. Moreover, it was observed that satisfactory coagulation was not caused by heat treatment in the original green juice

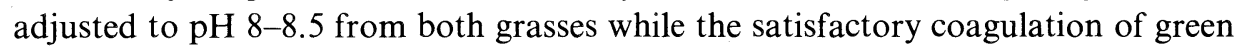
juice from legume crops was achieved under the same conditions. The effect of addition of $\mathrm{CaCl}_{2}$ to the $\mathrm{pH}$ adjusted (8.0-8.5) juice on the leaf protein coagulation was tested and the results are shown in Table 1. The addition of $\mathrm{Ca}$ caused the coagulation of the green juice from the grasses, but the green juices from the grass and legume crops differed widely in the $\mathrm{Ca}$ requirement for effective coagulation. The satisfactory coagulation was caused at a high Ca concentration $(261 \mathrm{mg} / 100 \mathrm{~g}$ juice) in the juice from Italian ryegrass while at a low Ca concentration $(88 \mathrm{mg} / 100 \mathrm{~g}$ juice) in that from red clover. Accordingly, it may be conceivable that there are some other factors which affect the firmness of the leaf protein curd, such as the amount of conjugated lipids of leaf proteins, though the Ca concentration appears to be main factor which causes the formation of coagulum on heat treatment under 
Table 1. Effect of Ca concentration $(\mathrm{mg} / 100 \mathrm{~g}$ juice) on the coagulation of green juice at $\mathrm{pH} 8-8.5$.

\begin{tabular}{|c|c|c|c|c|c|}
\hline \multirow{2}{*}{ Green juice } & \multicolumn{2}{|c|}{ Estimated value } & \multirow{2}{*}{$\begin{array}{l}\text { Amount of } \\
\text { added } \mathrm{Ca}\end{array}$} & \multirow{2}{*}{$\begin{array}{c}\text { Total amount } \\
\text { of } \mathrm{Ca}\end{array}$} & \multirow{2}{*}{ Coagulum $^{\mathrm{a}}$} \\
\hline & $\mathrm{Ca}$ & $\mathrm{Mg}$ & & & \\
\hline Alfalfa & 142 & 24 & - & 142 & ++ \\
\hline Red clover & 88 & 24 & - & 88 & ++ \\
\hline Italian ryegrass & 41 & 11 & - & 41 & - \\
\hline , & 41 & 11 & 55 & 96 & - \\
\hline , & 41 & 11 & 110 & 151 & $(+)$ \\
\hline ", & 41 & 11 & 165 & 206 & + \\
\hline ", & 41 & 11 & 220 & 261 & ++ \\
\hline Oats & 31 & 14 & - & 31 & - \\
\hline ", & 31 & 14 & 55 & 86 & + \\
\hline " & 31 & 14 & 110 & 141 & ++ \\
\hline
\end{tabular}

${ }^{\mathrm{a}}$ Green juice was tested for the formation of coagulum at $\mathrm{pH} 8-8.5$ by heating to $85^{\circ} \mathrm{C}$ for $10 \mathrm{~min}$. -, coagulation was not observed, or a finely dispersed coagulum which was difficult to separate by filtration; $(+)$, partial coagulation; + , soft coagulum; ++ , firm coagulum.

the mild alkaline condition.

\section{Chemical composition}

The chemical and mineral composition of freeze-dried leaf protein is shown in Table 2. Alfalfa leaf protein coagulated at $\mathrm{pH} 4$ contained a lesser amount of crude protein than the other two proteins. On the contrary, the $\mathrm{pH} 8$-coagulated proteins from red clover, Italian ryegrass and oats gave the lowest value of crude protein, largely due to the co-precipitation of carbohydrates (N-free extract, NFE) and minerals. This tendency was marked for the grass crops, Italian ryegrass and oats, and the greatest differences in crude protein and crude ash were observed between $\mathrm{pH} 8$ and the other $\mathrm{pH}$ levels for both grasses. The eighth column in Table 2 indicates that the $\mathrm{Ca}$ contents in the $\mathrm{pH} 8$-coagulated proteins from grass crops were significantly higher than those in the $\mathrm{pH} 8$-coagulated proteins from legume crops. Therefore, the remarkably high content of crude ash in the $\mathrm{pH} 8$-coagulated proteins from the grasses was attributed to the co-precipitation of the added $\mathrm{Ca}$ salt in the green juice.

As can be seen from Table 2, in each crop, the $\mathrm{pH}$ 6-coagulated protein contained a higher amount of crude fat and a lower amount of NFE than the leaf proteins coagulated at $\mathrm{pH} 4$ and 8 , excluding NFE in alfalfa leaf protein. The amount of NFE in alfalfa leaf proteins coagulated at $\mathrm{pH} 6$ and 8 was very low as compared with that of the $\mathrm{pH}$ 4-coagulated protein. Alfalfa may be different from the other crops in the type of NFE compounds of leaf protein.

It will be also noted from Table 2 that $\mathrm{Ca}, \mathrm{Mg}$ and $\mathrm{P}$ contents increased with the 
NUTRITIVE QUALITY OF LEAF PROTEINS

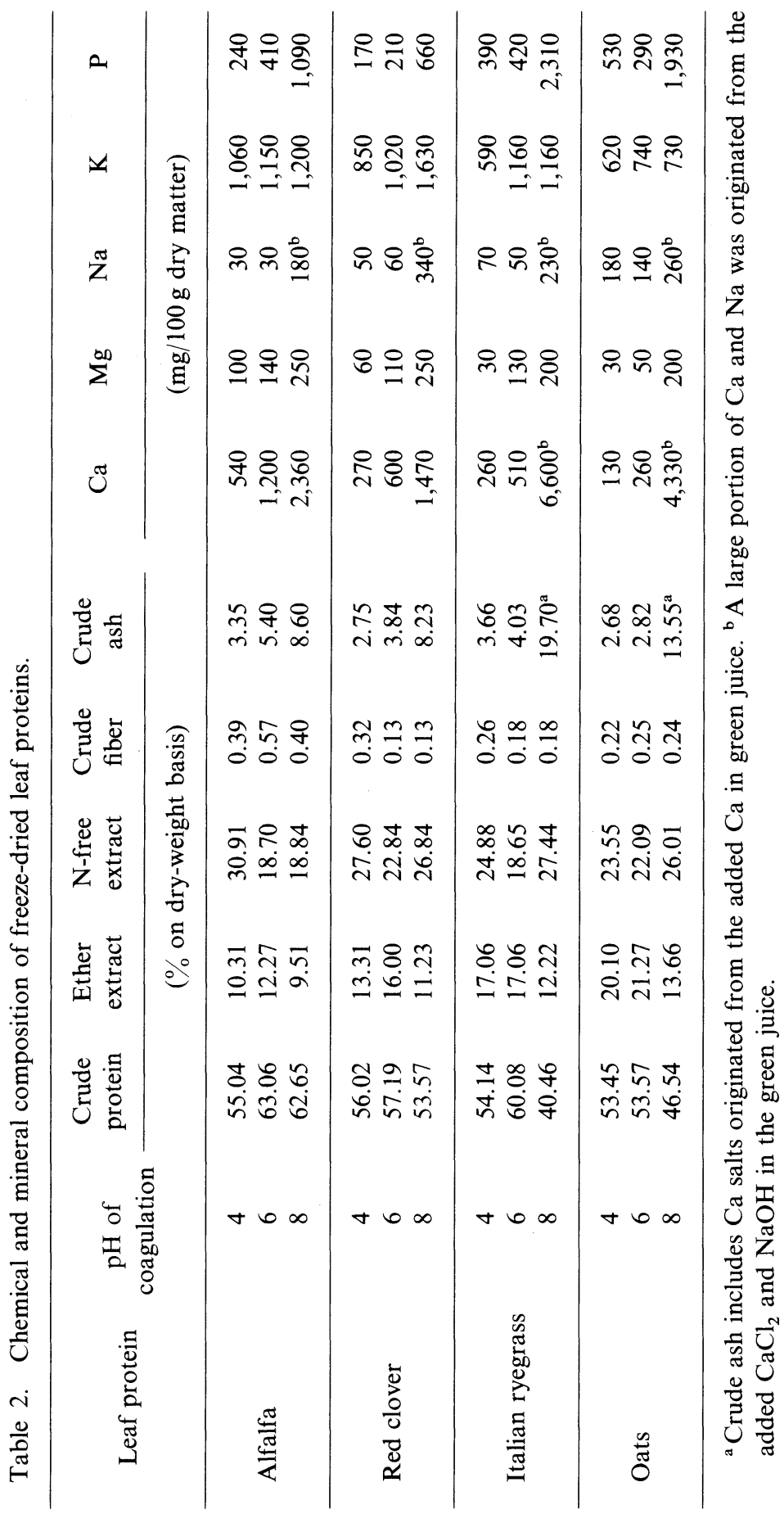


Table 3. Chemical composition of acetone-washed leaf proteins $(\%$ on dry-weight basis).

\begin{tabular}{lccccccc}
\hline \multirow{2}{*}{ Leaf protein } & $\begin{array}{c}\text { pH of } \\
\text { coagulation }\end{array}$ & $\begin{array}{c}\text { Crude } \\
\text { protein }\end{array}$ & $\begin{array}{c}\text { Ether } \\
\text { extract }\end{array}$ & $\begin{array}{c}\text { N-free } \\
\text { extract }\end{array}$ & $\begin{array}{c}\text { Crude } \\
\text { fiber }\end{array}$ & $\begin{array}{c}\text { Crude } \\
\text { ash }\end{array}$ & $\begin{array}{c}\text { Nucleic } \\
\text { acid }\end{array}$ \\
\hline \multirow{3}{*}{ Alfalfa } & 4 & 69.53 & 1.38 & 24.88 & 0.80 & 3.41 & 1.96 \\
& 6 & 76.01 & 0.99 & 15.81 & 0.65 & 6.54 & 1.51 \\
& 8 & 70.90 & 1.31 & 17.41 & 0.71 & 9.67 & 1.88 \\
\hline \multirow{3}{*}{ Red clover } & 4 & 65.16 & 2.04 & 29.88 & 0.37 & 2.55 & 1.92 \\
& 6 & 73.07 & 1.05 & 21.27 & 0.45 & 4.16 & 1.51 \\
& 8 & 67.99 & 1.22 & 21.76 & 0.44 & 8.68 & 1.70 \\
\hline \multirow{3}{*}{ Italian ryegrass } & 4 & 68.53 & 1.68 & 24.28 & 1.36 & 4.15 & 3.31 \\
& 6 & 70.73 & 1.11 & 20.94 & 2.22 & 5.00 & 2.21 \\
& 8 & 48.26 & 1.83 & 28.25 & 0.21 & $21.45^{\mathrm{a}}$ & 2.46 \\
\hline \multirow{2}{*}{ Oats } & 4 & 70.10 & 3.96 & 22.18 & 0.28 & 3.48 & 4.93 \\
& 6 & 69.85 & 3.98 & 21.87 & 0.32 & 3.98 & 2.07 \\
& 8 & 50.18 & 2.94 & 31.14 & 0.38 & $15.36^{\mathrm{a}}$ & 2.33 \\
\hline
\end{tabular}

${ }^{\text {a }}$ Crude ash includes $\mathrm{Ca}$ salt originated from the added $\mathrm{Ca}$ in green juice.

increasing $\mathrm{pH}$ of coagulation, excluding the $\mathrm{P}$ content of oats. Such a tendency was not observed in $\mathrm{K}$ and $\mathrm{Na}$ contents, but the highest content of $\mathrm{Na}$ was found in the $\mathrm{pH} 8$-coagulated proteins. It is apparent that the mineral content of leaf proteins depends on the ion binding capacity of the proteins and on the amount of salts which are co-precipitated with the protein from the green juice as a result of the effect of $\mathrm{pH}$ on the solubility of salts.

The chemical composition of acetone-washed leaf proteins is presented in Table 3. It is observed that crude protein, NFE and crude ash contents in the acetone-washed leaf proteins varied with the $\mathrm{pH}$ of coagulation in a similar manner as those in the freeze-dried leaf proteins. It will be observed, however, by comparing figures in Table 2 with the corresponding figures in Table 3 that washing of the wet protein curd with acetone caused a great increase in the crude protein content of leaf protein preparation, while the same treatment caused only a small variation in NFE and crude ash contents. It can therefore be presumed that the acetone-washing treatment not only removed most of the crude fat but also some of the NFE and crude ash. Table 3 also shows that in each crop, the $\mathrm{pH}$ 4-coagulated protein contained a higher amount of nucleic acid while the $\mathrm{pH}$ 6-coagulated protein contained a lower amount.

\section{Amino acid composition}

The amino acid contents of various acetone-washed leaf proteins are given in 
Table 4. Amino acid composition of leaf proteins coagulated at different $\mathrm{pH}$.

( $\mathrm{g}$ amino acid per $100 \mathrm{~g}$ recovered amino acids)

\begin{tabular}{|c|c|c|c|c|c|c|c|c|c|c|c|c|}
\hline \multirow{2}{*}{$\begin{array}{l}\text { Amino } \\
\text { acid }\end{array}$} & \multicolumn{3}{|c|}{$\begin{array}{c}\text { Alfalfa leaf } \\
\text { protein }\end{array}$} & \multicolumn{3}{|c|}{$\begin{array}{l}\text { Red clover } \\
\text { leaf protein }\end{array}$} & \multicolumn{3}{|c|}{$\begin{array}{l}\text { Italian ryegrass } \\
\text { leaf protein }\end{array}$} & \multicolumn{3}{|c|}{ Oats leaf protein } \\
\hline & $\mathrm{pH} 4$ & pH 6 & $\mathrm{pH} 8$ & $\mathrm{pH} 4$ & pH 6 & pH 8 & $\mathrm{pH} 4$ & pH 6 & pH 8 & $\mathrm{pH} 4$ & $\mathrm{pH} 6$ & $\mathrm{pH} 8$ \\
\hline Lys & 6.53 & 6.24 & 6.79 & 6.36 & 6.58 & 6.48 & 6.38 & 6.79 & 6.88 & 6.39 & 6.14 & 6.78 \\
\hline His & 2.52 & 2.57 & 2.51 & 2.44 & 2.58 & 2.55 & 2.43 & 2.31 & 2.39 & 2.52 & 2.56 & 2.71 \\
\hline Arg & 6.39 & 6.55 & 6.66 & 6.41 & 6.59 & 6.40 & 6.67 & 6.47 & 6.44 & 6.33 & 6.41 & 6.49 \\
\hline Asp & 10.31 & 10.08 & 10.42 & 10.42 & 10.49 & 10.69 & 9.83 & 9.36 & 9.55 & 9.65 & 9.43 & 9.45 \\
\hline Thr & 5.29 & 5.28 & 5.42 & 5.45 & 5.28 & 5.38 & 5.11 & 4.97 & 4.95 & 5.18 & 5.56 & 4.99 \\
\hline Ser & 4.63 & 4.42 & 4.56 & 4.84 & 4.70 & 4.83 & 4.73 & 4.65 & 4.71 & 4.61 & 4.49 & 4.44 \\
\hline Glu & 11.11 & 11.06 & 10.99 & 11.99 & 11.63 & 11.94 & 11.59 & 11.02 & 11.39 & 11.59 & 11.20 & 11.62 \\
\hline Pro & 5.59 & 6.01 & 5.88 & 4.25 & 4.67 & 4.71 & 4.78 & 4.88 & 5.03 & 4.51 & 4.66 & 4.66 \\
\hline Gly & 5.43 & 5.39 & 5.42 & 5.68 & 5.52 & 5.49 & 6.08 & 5.95 & 6.00 & 6.11 & 5.89 & 5.97 \\
\hline Ala & 6.49 & 6.12 & 6.25 & 6.15 & 6.13 & 6.31 & 6.91 & 6.94 & 6.93 & 6.72 & 6.75 & 7.00 \\
\hline Val & 6.78 & 6.77 & 6.74 & 7.20 & 7.20 & 7.02 & 6.91 & 6.84 & 6.75 & 6.93 & 6.96 & 6.71 \\
\hline Met & 1.94 & 2.07 & 2.04 & 1.77 & 1.75 & 1.86 & 2.15 & 2.29 & 2.20 & 1.94 & 2.15 & 2.09 \\
\hline Ile & 6.07 & 6.15 & 5.65 & 5.93 & 5.98 & 5.79 & 5.77 & 6.03 & 5.92 & 6.11 & 6.17 & 6.21 \\
\hline Leu & 9.83 & 9.97 & 9.78 & 9.81 & 9.73 & 9.54 & 9.56 & 10.10 & 9.80 & 9.75 & 9.90 & 9.73 \\
\hline Tyr & 4.68 & 4.70 & 4.57 & 4.89 & 4.80 & 4.78 & 4.52 & 4.64 & 4.59 & 4.72 & 4.73 & 4.52 \\
\hline Phe & 6.41 & 6.62 & 6.32 & 6.41 & 6.37 & 6.23 & 6.58 & 6.76 & 6.47 & 6.94 & 7.00 & 6.63 \\
\hline $\begin{array}{l}\text { Yield } \\
\text { of N } \%\end{array}$ & 84.96 & 87.00 & 84.09 & 77.50 & 81.10 & 79.58 & 79.59 & 89.42 & 87.93 & 83.72 & 91.60 & 88.88 \\
\hline $\begin{array}{l}\text { True } \\
\text { protein } \\
(\%)^{\mathrm{a}}\end{array}$ & 59.07 & 66.13 & 59.62 & 50.50 & 59.26 & 54.11 & 54.54 & 63.26 & 42.44 & 58.69 & 63.98 & 44.60 \\
\hline
\end{tabular}

${ }^{a}$ Crude protein content $(\%)$ in dry matter $\times$ yield of nitrogen per cent.

Table 4. No major or significant differences were found among the leaf proteins coagulated at different $\mathrm{pH}$. Furthermore, as pointed out by many workers $(11,12)$, there was a similarity in the amino acid composition of the various leaf proteins obtained from different crops.

The second row from the bottom in Table 4 shows the yield of nitrogen per cent which was obtained by the summation of amino acid nitrogen as $\%$ of total nitrogen in each leaf protein and is a useful check for the contamination of non-protein nitrogen compounds in a protein material. The yield for the $\mathrm{pH}$ 4-coagulated protein was lower than those for the proteins coagulated at $\mathrm{pH} 6$ and 8, excluding alfalfa. Such lower yields for the $\mathrm{pH}$ 4-coagulated protein may be associated with a larger amount of nucleic acid and other non-protein nitrogen compounds in them. The value calculated by multiplying the crude protein content by the yield of nitrogen per cent was tentatively taken as the true protein value and the values are presented on the last row of Table 4 . It is noted that the $\mathrm{pH}$ 6-coagulated protein 
Table 5. Diet intake, weight gain, digestibility and PER of male rats fed on a diet containing leaf protein coagulated at different $\mathrm{pH}$.

\begin{tabular}{lccccc}
\hline Leaf protein & $\begin{array}{c}\mathrm{pH} \text { of } \\
\text { coagulation }\end{array}$ & $\begin{array}{c}\text { Diet intake } \\
\text { for 14d. } \\
(\mathrm{g})\end{array}$ & $\begin{array}{c}\text { Weight gain } \\
\text { for } 14 \mathrm{~d} . \\
(\mathrm{g})\end{array}$ & $\begin{array}{c}\text { Digestibility } \\
\text { of protein } \\
(\%)\end{array}$ & PER \\
\hline \multirow{3}{*}{ Alfalfa } & 4 & $115.3 \pm 0.7$ & $39.3 \pm 2.0$ & $80.2 \pm 1.2$ & $3.83 \pm 0.19$ \\
& 6 & $115.8 \pm 0.3$ & $39.5 \pm 1.1$ & $79.7 \pm 1.5$ & $3.83 \pm 0.11$ \\
& 8 & $115.7 \pm 0.5$ & $38.9 \pm 0.6$ & $81.2 \pm 1.4$ & $3.78 \pm 0.07$ \\
\hline \multirow{2}{*}{ Red clover } & 4 & $115.2 \pm 0.6$ & $33.0 \pm 1.2$ & $74.2 \pm 2.0$ & $3.46 \pm 0.09$ \\
& 6 & $115.4 \pm 0.6$ & $34.1 \pm 2.5$ & $76.3 \pm 1.5$ & $3.56 \pm 0.23$ \\
& 8 & $115.8 \pm 0.2$ & $34.4 \pm 1.2$ & $78.1 \pm 0.6$ & $3.58 \pm 0.11$ \\
\hline \multirow{2}{*}{ ryegrass } & 4 & $115.5 \pm 0.4$ & $40.0 \pm 1.2$ & $78.3 \pm 1.6$ & $3.92 \pm 0.12$ \\
& 6 & $115.5 \pm 0.4$ & $38.0 \pm 1.4$ & $77.3 \pm 1.6$ & $3.72 \pm 0.13^{*}$ \\
& 4 & $115.7 \pm 0.2$ & $33.2 \pm 1.7$ & $76.1 \pm 0.7$ & $3.50 \pm 0.18$ \\
Oats & 8 & $115.5 \pm 0.5$ & $28.7 \pm 2.4^{*}$ & $71.3 \pm 1.7^{*}$ & $3.00 \pm 0.25^{*}$ \\
\hline
\end{tabular}

PER, g weight gain/g protein intake. Values are the means \pm SD. ${ }^{*}$ Significantly different from the value of the corresponding leaf protein coagulated at lower $\mathrm{pH}(p<0.05)$.

had the highest value of true protein in each crop.

\section{Biological test}

The growth data, apparent digestibilities and PER values obtained with the acetone-washed leaf proteins are shown in Table 5. In the case of legume crops, alfalfa and red clover, there were no differences in the growth performance of rats fed on the leaf proteins coagulated at different $\mathrm{pH}$ from each crop. Livingston et al. (2) pointed out that the saponin content of alfalfa leaf protein prepared at an alkaline $\mathrm{pH}$ was lesser than that of leaf proteins prepared at a lower $\mathrm{pH}$. The alfalfa leaf proteins used for our experiment were prepared by washing the wet leaf protein curd with acetone and accordingly, it is probable that the $\mathrm{pH}$ 4-coagulated protein contained a small amount of saponin as the $\mathrm{pH} 8$-coagulated protein. In other words, it can be concluded that the reverse effect of saponin on the nutritional quality of the leaf protein washed with acetone was negligible. Therefore, the nutritional quality of acetone-washed leaf proteins made from the legume crops was not influenced by the $\mathrm{pH}$ of coagulation.

In Italian ryegrass, the PER value of the $\mathrm{pH}$ 6-coagulated protein was significantly lower than that of the $\mathrm{pH}$ 4-coagulated protein but the difference 
Table 6. Diet intake, amount of feces and crude ash content in feces in male rats fed on a diet containing leaf protein coagulated at different $\mathrm{pH}$.

\begin{tabular}{lcccc}
\hline Leaf protein & $\begin{array}{c}\mathrm{pH} \text { of } \\
\text { coagulation }\end{array}$ & $\begin{array}{c}\text { Diet intake } \\
\text { for 3d. (g) }\end{array}$ & $\begin{array}{c}\text { Feces } \\
\text { for 3d. }(\mathrm{g})\end{array}$ & $\begin{array}{c}\text { Crude ash } \\
\text { in feces }(\%)\end{array}$ \\
\hline \multirow{3}{*}{ Red clover } & 4 & $25.8 \pm 0.2$ & $1.56 \pm 0.12$ & $6.26 \pm 0.20$ \\
& 6 & $26.0 \pm 0.1$ & $1.34 \pm 0.08$ & $6.43 \pm 0.81$ \\
& 8 & $25.9 \pm 0.1$ & $1.42 \pm 0.04$ & $14.24 \pm 0.94^{*}$ \\
\hline \multirow{2}{*}{ Italian ryegrass } & 4 & $25.9 \pm 0.1$ & $1.49 \pm 0.05$ & $7.21 \pm 0.23$ \\
& 8 & $25.8 \pm 0.3$ & $2.81 \pm 0.14^{*}$ & $33.82 \pm 1.07^{*}$ \\
\hline \multirow{2}{*}{ Oats } & 4 & $29.8 \pm 0.3$ & $1.29 \pm 0.10$ & $7.27 \pm 1.01$ \\
& 6 & $29.4 \pm 0.8$ & $1.37 \pm 0.06$ & $8.03 \pm 0.22$ \\
& 8 & $29.7 \pm 0.2$ & $2.22 \pm 0.22^{*}$ & $27.49 \pm 0.84^{*}$ \\
\hline
\end{tabular}

Values are the means \pm SD. ${ }^{*}$ Significantly different from the value of the corresponding leaf protein coagulated at lower $\mathrm{pH}(p<0.01)$.

between the values of the two proteins was very small. On the other hand, significant differences in body weight gain, apparent digestibility and PER value between the leaf proteins coagulated at $\mathrm{pH} 4$ and 8 were observed. The $\mathrm{pH} 8$ coagulated protein made from oats was significantly different in apparent digestibility from the proteins coagulated at $\mathrm{pH} 4$ and 6 . It seems reasonable to presume that the depression of the nutritional quality of the $\mathrm{pH}$ 8-coagulated proteins was due to the remarkable high content of crude ash in it. Table 6 shows the quantity of feces voided and crude ash content in feces of rats fed on various leaf proteins made from red clover, Italian ryegrass and oats. It is indicated that the quantity and ash content of feces of rats fed on the $\mathrm{pH} 8$-coagulated proteins made from Italian ryegrass and oats were remarkably larger than those of rats fed other leaf proteins, while the feeding of the $\mathrm{pH}$ 8-coagulated protein from red clover caused only a higher ash content in feces. These results suggest that the addition of a large amount of $\mathrm{Ca}$ salt into the green juice to induce the coagulation of leaf protein under the mild alkaline condition caused the depression of nutrional quality of the coagulated protein.

The data presented in this work support that in general, the leaf protein produced by heating the green juice without any adjustment of $\mathrm{pH}$ may be suitable for protein resources because of a high true protein content and good nutritional quality.

The authors are grateful to Emeritus Professor M. Kandatsu, University of Tokyo, for his interest in this work. 


\section{REFERENCES}

1) Subba Rau, B. H., and Singh, N. (1970): Studies on nutritive value of leaf protein from lucern. Indian J. Exp. Biol., 8, 34-36.

2) Livingston, A. L., Knuckles, B. E., Edwards, R. H. de Fremery, D., Miller, R. E., and Kohler, G. O. (1979): Distribution of saponin in alfalfa protein recovery systems. $J$. Agric. Food Chem., 27, 362-365.

3) Hegsted, M., and Linkswiler, H. M. (1980): Protein quality of high and low saponin alfalfa protein concentrate. J. Sci. Food Agric., 31, 777-781.

4) Enochian, R. V., Kohler, G. O., Edwards, R. H., Kuzmicky, D. D., and Vosloh, C. J. (1980): Producing Pro-Xan (leaf protein concentrate) from alfalfa. Agricultural Economic Report No. 445, United States Dept. Agric., pp. 1-37.

5) Methods of Analysis-A.O.A.C. (1975): ed. by Horwitz, W., Association of Official Analytical Chemist, Washington, D.C.

6) Shokuhin no Kikibunseki (1971): ed. by Kanomata, K., Yamaoka, Y., Harada, A., and Tajima, K., Korin Shoin, Tokyo, pp. 813-835.

7) Nakamura, M. (1950): Colorimetric determination of phosphorus. Nippon Nogeikagaku Kaishi (J. Agric. Chem. Soc. Jpn.), 24, 1-5.

8) Jikken Kagaku Koza Vol. 23 (1958): ed. by Nippon Kagaku Kai, Maruzen, Tokyo, pp. 281-288.

9) Horigome, T., and Uchida, S. (1980): An observation on the nutritional quality of leaf protein in connexion with its methionine content. Nippon Chikusan Gakkaiho (Jpn. J. Zootech. Sci.), 51, 429-435.

10) Phillips, P. H., and Hart, E. B. (1935): The effect of organic dietary constituents upon chronic fluorine toxicosis in the rat. J. Biol. Chem., 109, 657-663.

11) Byers, M. (1971): The amino acid composition of some leaf protein preparations, in Leaf Protein, ed. by Pirie, N. W., Blackwell Scientific Publ., Oxford and Edinburgh, pp. 95-114.

12) Pirie, N. W. (1978): Leaf Protein and Other Aspects of Fodder Fractionation, Cambridge Univ. Press, Cambridge, pp. 57-61. 